\title{
Aggressive Central Giant Cell Granuloma: A Case Report
}

\author{
Jahangir Hammad ${ }^{1}$, Muhammad Ayoub², Kashaf-ud-doja Tariq ${ }^{2}$, Farhat Gul Babar ${ }^{2}$ \\ ${ }^{1}$ Associate professor, Department of Oral and Maxillofacial surgery, Sandeman Provincial hospital, BUMHS, Quetta \\ ${ }^{2}$ Resident, Department of Oral and Maxillofacial surgery, Sandeman Provincial hospital, BUMHS, Quetta
}

\begin{abstract}
A B S T R ACT
Central giant cell granuloma (CGCG) is a benign non odontogenic lesion of jaw that may show aggressive behavior. It is classified as aggressive and non-aggressive lesion on the basis of biological behavior and radiographic features. Central giant cell lesion is more frequent in children and young adult before the age of 30 years with female predilection, with characteristic radiological and histopathological features. Here we present a case of a 35 years old female with clinical and radiological diagnosis of central giant cell lesion in posterior mandible confirmed by histopathology. A surgical approach with regular follow up is the treatment of choice in most of the cases.

Key Words: Calcitonin, Corticosteroid, Curettage, Enucleation, Giant cell lesion

\begin{tabular}{|c|c|}
\hline Correspondence: & Article info: \\
\hline Kashaf-ud-doja Tariq & Received: October 21,20 \\
\hline Email:memahmood1945@gmail.com & Accepted: February 6, 20 \\
\hline
\end{tabular}
10.35787/jimdc.v9i1.428

\section{Introduction}

Central giant cell granuloma (CGCG) is a giant cell lesion, that represents a benign proliferation of fibroblasts and multinucleated giant cells. ${ }^{1}$ Kaban and colleagues formalized a classification system that provides a guide for treatment. ${ }^{2}$ The biological behavior can be aggressive or non-aggressive, in which aggressive form exhibits numerous symptoms whereas non aggressive is asymptomatic. ${ }^{1}$ The aggressive form has any three of the following criteria; greater than $5 \mathrm{~cm}$, painful, rapid growth, root resorption, tooth displacement, cortical bone thinning or perforation, extension into soft tissue, ulceration of overlying mucosa and recurrence. The non-aggressive lesion is relatively small, painless, exhibits few or no symptoms, grows slowly, and does not cause root perforation or root resorption. ${ }^{1}$ Central giant cell granuloma mostly occurs in children and young adults with female predilection.
The mandible is affected more frequently than maxilla (3:1), mostly anterior to the first permanent molar teeth. Lesion may be seen crossing midline. ${ }^{1}$ Central giant cell granuloma resembles other giant cell lesions so proper clinical examination, histological and radiographic analysis, helps to differentiate it from these lesions. ${ }^{3}$

\section{Case Report}

A 35 years old female came to Oral and Maxillofacial Surgery Department with complaint of pain and swelling on the right side of lower jaw, which appeared 6 months back. Patient was referred by a general dentist. Pain radiated to the head region and was only relieved by analgesics. Swelling progressively increased in size due to which patient was unable to eat. It was not associated with fever, chills, rigors and lymphadenopathy. 
Past medical, surgical, drug and family history were unremarkable. Patient was a housewife with 3 children and belonged to a middle-class family. She was well oriented in time place and person. There was no anemia, jaundice, cyanosis, clubbing or lymphadenopathy. On clinical examination, there was facial asymmetry due to swelling on right lower side of the face. Mouth opening was adequate with a firm swelling of approximately $5 \mathrm{~cm}$, extending superiorly to occlusal level of teeth, inferiorly to buccal vestibule, anteriorly to first premolar and posteriorly to third molar region. The overlying mucosa was normal. Teeth associated with swelling were mobile.

Baseline investigations were normal. Orthopantomograph revealed radiolucent swelling $4 \mathrm{~cm} \times 2 \mathrm{~cm}$ in size on right posterior mandible with bone resorption and displacement of associated teeth (Figure 1). On Incisional biopsy, microscopic features such as few multinucleated giants in a background of plump proliferating mesenchymal cells along with red blood cells extravasation confirmed central giant cell granuloma (CGCG). Surgery was performed under General anesthesia with enucleation (complete removal of lesion) and curettage, along with extraction of the associated teeth and peripheral ostectomy to prevent recurrence. First, incision was marked to ensure that it was placed over an area of sound bone that allow for adequate tissue closure as placement of incision over a bony defect may allow the wound to break down in to the lesion cavity. A small round bur was used for lateral corticotomy and sharp double end curette was used for enucleation. The sharp end of curette was used between the lesion and against the bone to allow proper enucleation of the lesion and minimize the occurrence of a tear. The cavity was then examined for any remnant. A peripheral ostectomy was completed with large round diamond bur with copious irrigation to remove 1-2 $\mathrm{mm}$ of surrounding bone until the cavity was completely cleared. Post-removal examination of lesion was done (Figure 2). Written consent was signed by the patient in which the disease, complications of disease and surgery and prognosis of surgical treatment was clearly explained.

Patient was recalled weekly for follow-up. In each visit wound was examined carefully, irrigated, dressing was placed in the intraoral wound to promote healing. Rehabilitation with prosthesis was planned after complete wound healing.

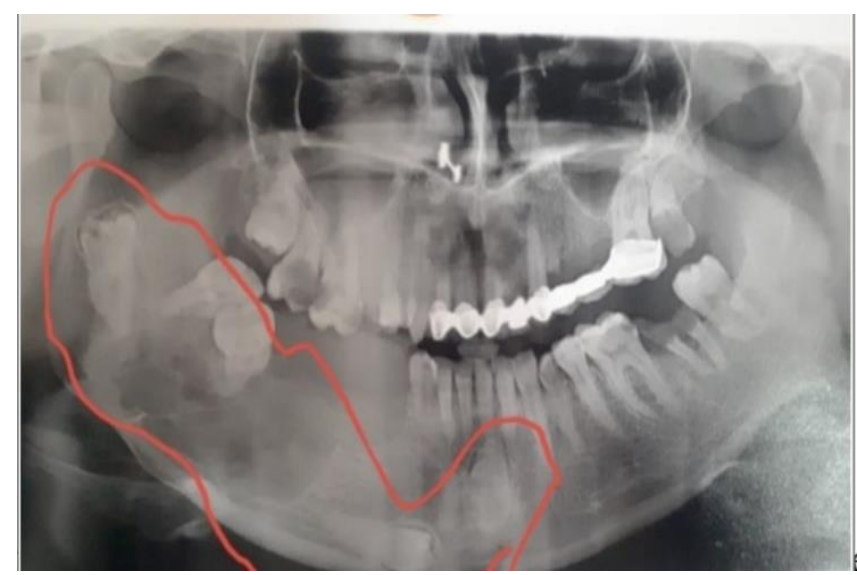

Figure 1: OPG showing radiolucency on right posterior mandible with bone resorption and teeth displacement.

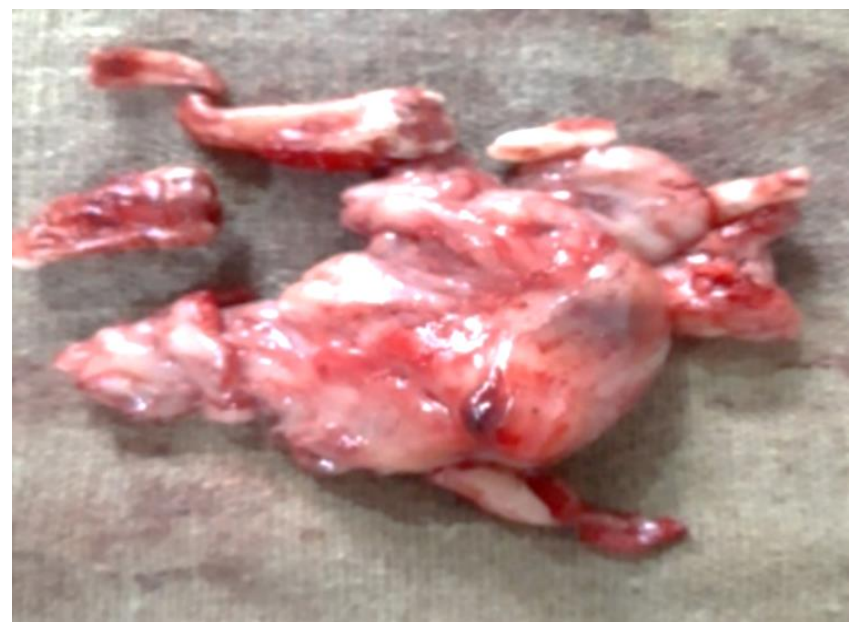

Figure 2: Gross specimen of CGCG after enucleation and peripheral ostectomy

\section{Discussion}

World health organization classified central giant cell granuloma in 2005 as the rarely aggressive lesion of jaw that may be asymptomatic or present 
with pain, paresthesia and bone perforation. ${ }^{4}$ Jaffee (1953) considered this lesion as reparative reaction of bone. ${ }^{5,6}$ Cossío et al suggested that trauma is the main cause of CGCG. ${ }^{7}$ Soames and Southam (1997) suggested that it could be a reaction to bone marrow hemodynamic disturbance. There are many orofacial giant cell lesions that have similar presentation so surgeon should have proper knowledge of histopathological and radiographic features to differentiate, diagnose and manage the lesion.

CGCG is frequently reported in females less than 30 years of age with anterior mandible as the most commonly affected site. ${ }^{4}$ However, our case was a 35 years old female with the lesion in posterior mandible. Medical treatment of this lesion includes intralesional corticosteroid injections for 6 weeks, subcutaneous calcitonin injections for 1 year, interferon alpha-2b subcutaneous injections or combination. ${ }^{8,9}$ Surgical treatment options include curettage alone (with more chances of recurrence) or curettage with enucleation, resection and peripheral ostectomy as the best treatment option. ${ }^{4}$

Intraoperative complications of these surgical procedures include damage to adjacent teeth and nerves, bleeding, and tearing of lesion lining. Postoperative complications include infection, wound dehiscence, graft failure, facial asymmetry, and recurrence. ${ }^{10}$

\section{Conclusion}

Central giant cell granuloma belongs to giant cell lesion group with unknown etiology. This pathological lesion is managed by taking proper history, examination, radiographic and, histopathological analysis that helps to differentiate it from other lesions. There are different treatment strategies for central giant cell granuloma with the choice depending upon patient's demand, medical condition of the patient, severity of the disease and surgeon experience.

\section{References}

1. Kumar N, Vande AV, Tewary S, Zope SA. Giant Cell Lesion and Central Giant Cell Granuloma. AABS. 2017; 4(1): 22-29. Doi: 10.21276/AABS.2017.1315

2. Kudva A, Cariappa KM, Dhara V, Solomon M. Central giant cell granuloma: An uncommon presentation. Oral Maxillofac Sur Cases. 2018; 4(4): 135-40. Doi: 10.1016/j.omsc.2018.08.001

3. Cavalcante RC, de Lucas Corso PF, Dias TR, Schramm $\mathrm{E}$, de Souza $\mathrm{PH}$, Rebellato $\mathrm{NL}$, et al. Central giant cell granuloma (CGCG) in childhood: surgical treatment by maintaining the tooth germs. RSBO Revista SulBrasileira de Odontologia. 2017; 14(1): 37-43.

4. Buduruk K, Podduturi SR, Prakesh J. Central giant cell granuloma: A case report and review. JIAOMnR .2017 April; 29(2): 145.

5. Sandhya T, Avinash T, Snehal D, Neha T, Uma M. Multifocal Central Giant Cell Granuloma - A Case Report. IJP. 2016;11(3):276.

6. Kaur N, Kohli T, Chhina AK. Central giant cell granuloma: A diagnostic predicament. J Adv Med Dent Scie Res. 2016; 4(1): 90.

7. Infante Cossío $P$, Martínez de Fuentes $R$, Carranza Carranza A, Torres Lagares D, Gutiérrez Pérez JL. Recurrent central giant cell granuloma in the mandible: Surgical treatment and dental implant restoration. Med Oral Patol Oral Cir Bucal (Internet). 2007 May; 12(3):229-32.

8. El Hadidi YN, Ghanem AA, Helmy I. Injection of steroids intralesional in central giant cell granuloma cases (giant cell tumor): is it free of systemic complications or not? A case report. Int J Surg Case Rep. 2015; 8:166-70. Doi: 10.1016/j.ijscr.2015.02.001

9. Rachmiel A, Emodi O, Sabo E, Aizenbud D, Peled M. Combined treatment of aggressive central giant cell granuloma in the lower jaw. J Craniomaxillofac Surg. 2012; 40(3): 292-7. Doi: 10.1016/j.jcms.2011.04.002

10. Bataineh AB, Al-Khateeb T, Ma'amon AR. The surgical treatment of central giant cell granuloma of the mandible. J Oral Maxillofac Surg. 2002 Jul 1;60(7):756-61. 